\title{
Spatial and Temporal Changes of Land Productivity East of The Nile River (Damietta Branch), Egypt
}

\author{
Ahmed S. Abuzaid \\ Soil and Water Department, Faculty of Agriculture, Benha University, Egypt
}

\begin{abstract}
$\mathbf{T}$
HE GROWING demand for food with a simultaneously increased population raised the pressure on land and soil resources. Hence, monitoring their productivity enable refining management practices in order to improve the performance. The current work aimed at evaluating spatial and temporal variations in the productive capacity of $2157.65 \mathrm{~km}^{2}(215765$ ha) located along the Nile River (Damietta branch), Egypt. The soils belong to three productivity classes; grade I (excellent), grade II (good) and grade III (average), representing 4.6, 79.3 and $16.1 \%$, respectively of the total area. Changes in the land productivity were observed during the last five decades. The positive changes are predominant in the majority of the studied soils $(76 \%)$, while the negative changes are in few localities (24\%). Excessive salt content, improper drainage conditions and texture/structure are the most effective limiting factors. Improving land productivity grade requires improving drainage conditions, leaching excessive salt, and addition of organic amendments.
\end{abstract}

Keywords: Land productivity, Land management, Land characteristics, East Nile River

\section{Introduction}

The increasing global population made food security a major challenge facing the modern world (Lairon, 2010 and Bents \& Silova, 2017). Hence, food production growth via increasing crop yield is much-needed to fulfill the growing food demand and alleviate poverty, especially in the developing countries (Badami \& Ramankutty, 2015 and Ciaian et al., 2017). Such increase heightens the pressure on land and soil resources, which are the key factor for providing sustainable production (Sasmal, 2016 and Murphy, 2017).

The cultivated area in the Nile Delta region is 4.4 million feddans (1.8 ha), representing 55\% of the cultivated area in Egypt (Mohamed, 2016). This vital portion undergoes factors that prohibit further agricultural development including urban sprawl (Gouda et al., 2016) and different types of degradation, which are related mainly to improper management practices (El Baroudy, 2011, Mohamed et al., 2013 and Arnous et al., 2015).

Land productivity is the overall productivity related to various factors including climate, parent material, topography, and soil physiochemical properties (Deng et al., 2011 and Zhou et al., 2012). Evaluating and monitoring the land productivity help in refining the agricultural practices to preserve soil capacity for producing food, fibers, and essential goods (Kudrat \& Saha, 1993 and Field, 2017). A systematic and timely flow of reliable data is a sine qua non for such goal (Bacic, 2008 and Bodaghabadi et al., 2015). Land productivity evaluation is usually performed directly or indirectly. Direct methods use experiments under given climatic conditions and controlled management practices which are carried out in the field, greenhouses or in the laboratory. Indirect methods depend on developing and applying models to estimate the productivity index (Dengiz \& Sağlam, 2012 and Baskan et al., 2017). The parametric model proposed by Riquier et al. (1970) is a well-known methodology for evaluating land productivity. It provides a single numerical index; land productivity index (LPI) derived from multiplication of soil characteristics related to plant growth (FAO, 2007).

Worldwide, Riquier approch has been used for asesseing and monitorng land productivity (Dengiz, 2007 and Setia et al., 2012). Agber and Ali (2012) reported that LPI is a valubale tool, therby monitoring soils productivity. This index correlates significantly with yield, thus it can actually clarify yield variations. In Egypt, Abdel 
Kawy and Belal (2013) reported positive changes in cultivated land productivity after 5 decades in El-Fayoum Depression due to the good land management practices. On the other hand, ElBaroudy (2015) found that negative changes were predominant after 4 decades cultivation in more than $70 \%$ of soils in the middle part of the Nile Delta. Improper land management practices increased soil salinity and alkalinity and raised water table. The current work aimed at evaluating the current and previous land productivity at east Nile River (Damietta branch), Egypt.

\section{Materials and Methods}

The study area

The area covers $2157.65 \mathrm{~km}^{2}$ along the Nile River (Damietta branch) between $31^{\circ} 13^{\prime} 07^{\prime \prime}$ and $32^{\circ} 04^{\prime} 51^{\prime \prime} \mathrm{E}$ and $30^{\circ} 35^{\prime} 16^{\prime \prime}$ and $30^{\circ} 36^{\prime} 12^{\prime \prime} \mathrm{N}$ (Fig. 1).According to EMA (2011), the climatic normal in the area is characterized by cold winter and hot arid summer. The total annual rainfall is $53.6 \mathrm{~mm}$, and the maximum amount occurs during January. The mean annual temperature is $20.3 \mathrm{C}^{\circ}$ with a value reaches $32.3 \mathrm{C}^{\circ}$ in August, while it decreases to $14.8 \mathrm{C}^{\circ}$ in January. The soil moisture regime is Torric and the soil temperature regime is Thermic (Soil Survey Staff, 2014a).

\section{Geomorphology}

The main landforms in the area are wetlands, gypsiferrous flats, clay flats, decantation basin, overflow basin, overflow mantle and river terraces (Fig. 2). A geomorphic map developed by Abdel
Kawy and Ali (2012) was used in the current study. This map was produced using digital processing of Landsat ETM+ satellite images and digital elevation model. The map was imported to Arc GIS 10.2.2 (ESRI, 2014), georeferenced and screen-on digitizing was performed to delineate different units to be used as a base for maps production.

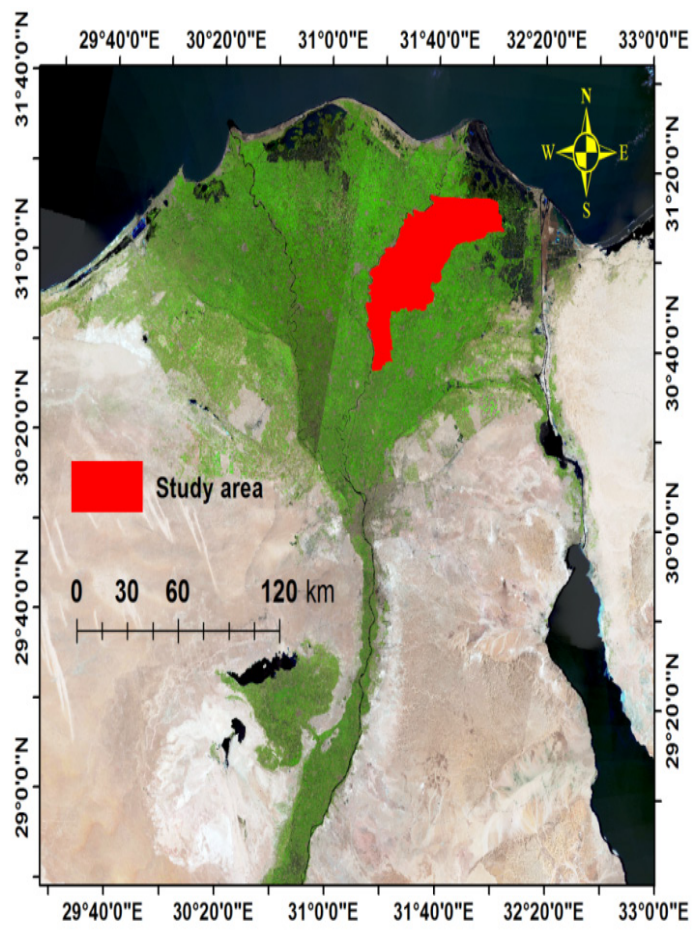

Fig. 1. Location map of the studied area
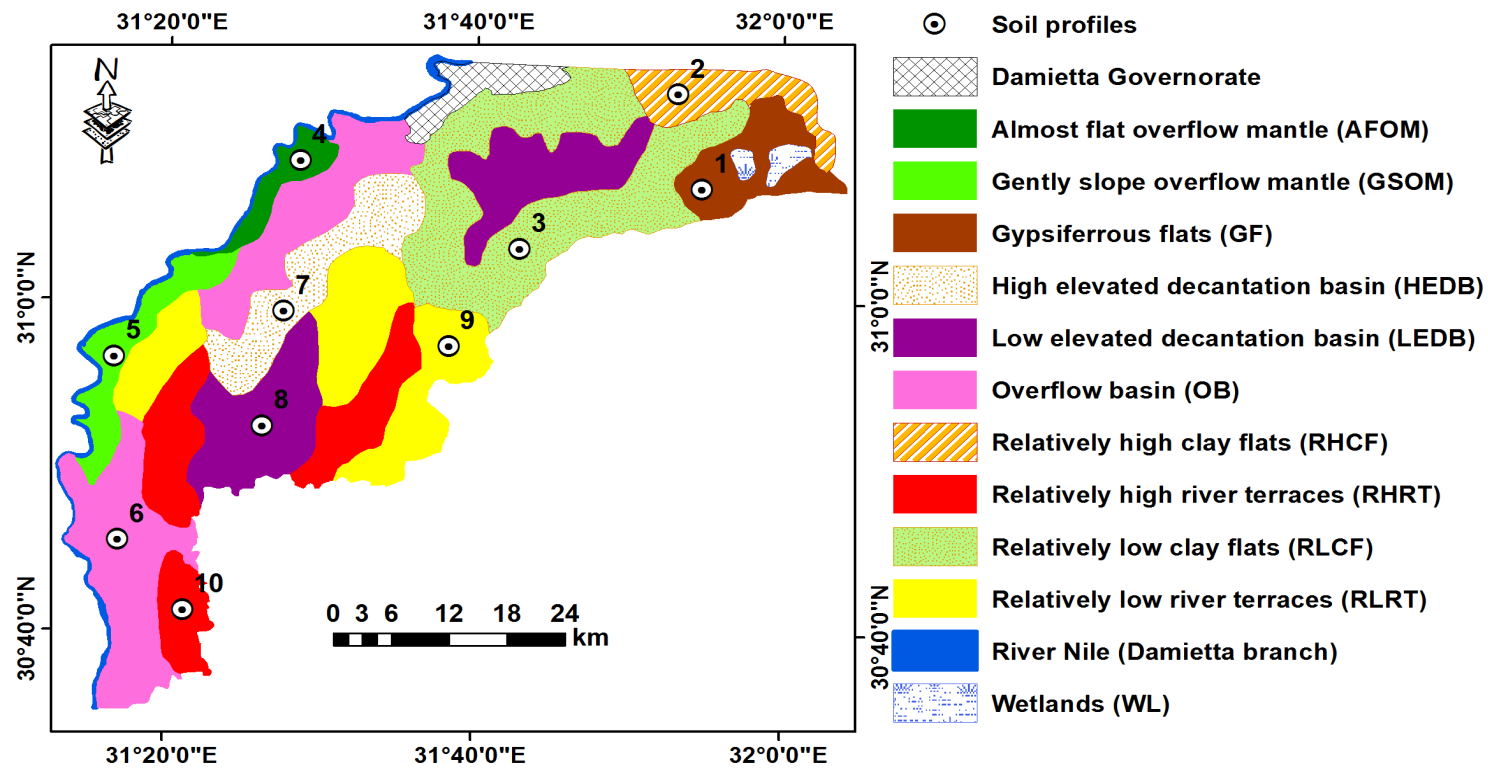

Fig. 2. Geomorphic map (After Abdel Kawy and Ali, 2012) and locations of soil profiles in the studied area

Egypt. J. Soil Sci. 57, No.4 (2017) 


\section{Field and laboratory investigations}

Ten soil profile pits representing the different geomorphic units in the studied area were dug to a depth of $150 \mathrm{~cm}$ or ground water table, whichever comes first. The locations of the selected soil profiles were the same sites previously studied by Soils, Water and Environment Research Institute (SWERI) during the second half of the sixties of the last century (SWERI, 1965, 1968 and 1969). The exact locations of the profiles (Fig. 2) were identified in the field using the Global Positioning System (Garmin GPS $72 \mathrm{H}$ ). The morphologic features of the profiles were identified following the basis of FAO (2006). Representative disturbed 30 soil samples were collected from the profiles. The laboratory analyses were performed following the standard methods of Soil Survey Staff (2014b).

\section{Land productivity assessment and monitoring}

Land productivity index (LPI) was calculated following the parametric method (Riquier et al., 1970). The ratings of moisture content $(\mathrm{H})$, drainage (D), soil depth (P), texture/structure (T), slope $(\mathrm{E}), \mathrm{pH}$ of the surface layer $(\mathrm{N})$, soluble salt $(\mathrm{S})$, organic matter $(\mathrm{O})$, cation exchange capacity (A), and mineral reserve (M) are multiplied to output the LPI as follows:

$$
\text { LPI }=\left(\frac{\mathrm{H}}{100} \times \frac{\mathrm{D}}{100} \times \frac{\mathrm{P}}{100} \times \frac{\mathrm{T}}{100} \times \frac{\mathrm{E}}{100} \times \frac{\mathrm{N}}{100} \times \frac{\mathrm{S}}{100} \times \frac{\mathrm{O}}{100} \times \frac{\mathrm{A}}{100} \times \frac{\mathrm{M}}{100}\right) \times 100
$$

The productivity classes and the corresponding LPI values are shown in Table 1. Changes in land productivity were evaluated based on the comparison between the data extracted from three reports (SWERI, 1965, 1968, 1969) and the data obtained from the current study.

\section{$\underline{\text { Results and Discussions }}$}

\section{Soils of the area}

Results in Table 2 indicate that the soils are flat to very gently sloping $(0.1-1.85 \%)$ and very deep (depth $>150 \mathrm{~cm}$ ), except the GF unit, as the soil is deep $(110 \mathrm{~cm})$. The soils are neutral to slightly alkaline with $\mathrm{pH}$ values ranging from 7.04 to 7.66 . EC varies from 1.03 to $6.59 \mathrm{dS} \mathrm{m}^{-1}$, indicating non

TABLE 1. Land productivity classes and indices

\begin{tabular}{lcc}
\hline Class & Symbol & LPI value \\
\hline Excellent & I & $65-100$ \\
Good & II & $35-64$ \\
Average & III & $20-34$ \\
Poor & IV & $8-19$ \\
Extremely poor to nil & V & $0-7$ \\
\hline
\end{tabular}

to slight salinity. Soil organic matter (OM) ranges from10.14 to $13.47 \mathrm{~g} \mathrm{~kg}^{-1}$. Cation exchange capacity (CEC) ranges from 29.28 and 38.08 cmolc $\mathrm{kg}^{-1}$ soil. Exchangeable sodium percentage (ESP) varies from 2.14 to 12.83 , indicating non-sodic soils $(<15 \%)$. Calcium carbonate and gypsum contents vary from 4.12 to $14.65 \mathrm{~g} \mathrm{~kg}^{-1}$ and from 6.45 to $188.30 \mathrm{~g} \mathrm{~kg}^{-1}$, respectively. Soil texture is clay in all the studied units, except soils of the GF unit (sandy clay) and the GSOM unit (clay loam). The soils are well drained, except the GF unit, where the soil is moderately well.

Moisture constants range from 34.81 to 41.12 for $\mathrm{FC}$, from 15.95 to 18.76 for PWP and from 18.86 to 22.36 for AW. Moisture availability is an important soil property for plant growth and maintaining the sustainability of agricultural ecosystems (Zhang et al., 2017). It is affected by clay and organic matter contents rather than other soil property (Ding et al., 2014 and Rong et al., 2017). According to Riquier et al. (1970) moisture availability in soil is determined by available water that seems in the current study to be above PWP and below FC, and hence moisture content rating is 100.Concerning mineralogy, Wahab \& Stanley (1991) and Abdou \& Shehata (2009) indicated that the area is covered by deposits of weatherable rock-derived minerals of igneous, metamorphic, and sedimentary rocks. The presence of high amount of weatherable minerals in soil provides a renewable source for plant nutrients and helps in fertility restoration (van Breemen et al., 2000 and Brocard et al., 2015). According to Riquier et al. (1970), the rating of mineral reserve is 100 .

\section{Monitoring soil characteristics in the studied area}

Selected soil properties were used to assess long-term changes in soil. The comparison based on modifiable soil properties, which are affected by land management practices such as soil depth, EC, ESP, pH, OM and CEC.Other soil properties were not considered, since they did not change. Slope, texture and mineral reserve are permanent properties which are difficult to be modified, while moisture availability is related to clay content.As shown in Fig. 3, groundwater table decreased in the current study in all units compared with the corresponding levels in the previous study, except in the GF unit where soil depth changed from very deep to deep.The positive changes are due to good draining networks, which allowed percolation of excessive water into deep soil. On the hand, inadequate drainage caused the current increase in groundwater table in the GF unit. Mueller et al. 


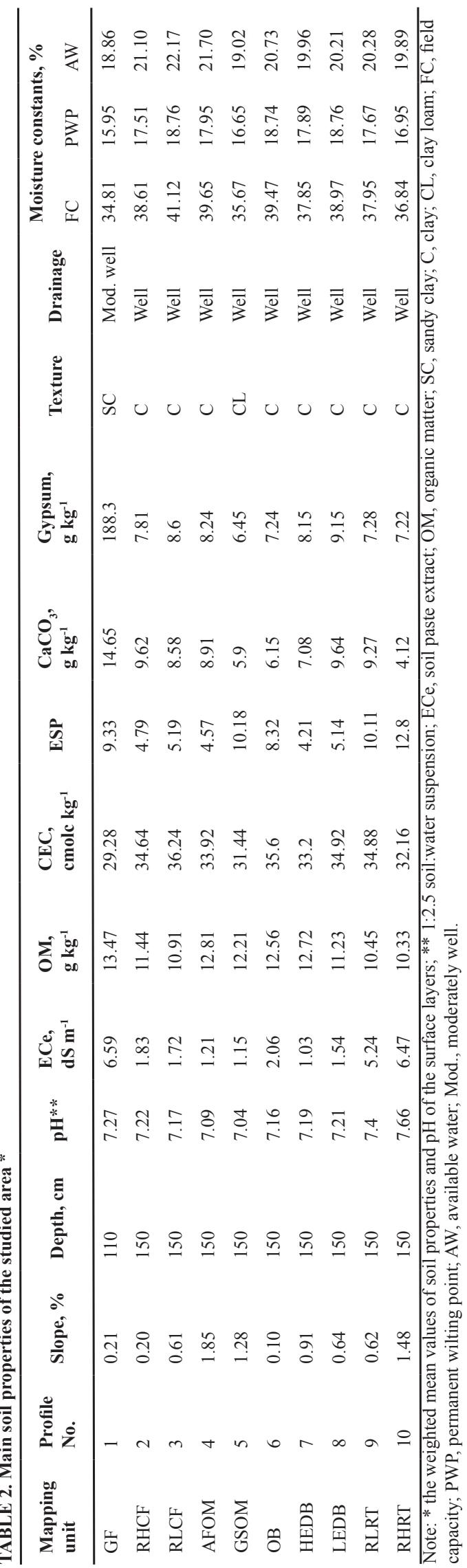

Egypt. J. Soil Sci. 57, No.4 (2017)
(2005) and Ruseckas et al. (2015) reported that perfect drainage lead to lowering groundwater table. As a result, EC and ESP decreased in the current study compared to the previous study (Fig. 4 and 5).

Soil salinity decreased from none to moderate $\left(1.54-13.87 \mathrm{dS} \mathrm{m}^{-1}\right)$ in the previous study to none to slight $\left(1.03-6.47 \mathrm{dS} \mathrm{m}^{-1}\right)$ in the current study. Also, sodicity decreased from none to moderate $(4.08-17.58 \%)$ in the previous study to none to slight $(3.98-12.83 \%)$ in the current study. However, there was a current increase in both EC and ESP related to three units; GF, OB and RHRT due to flood irrigation using brackish agricultural drainage water without adding leaching requirements. In this context, El-Saidi (2002) and Wahba (2017) reported that long-term irrigation using low quality agricultural drainage water in Egypt has a distinct influence in increasing soil salinity and sodicity. When the water enters the soil system, it is consumed by the growing plants, and the salts are left behind and eventually begin to accumulate in the soil (Ali, 2011). Also, van-den Akker et al. (2011) and Gao et al. (2015) reported that salt accumulation in the soil and shallow groundwater table significanly respond to flood irrigation in arid areas. Soil $\mathrm{pH}$ dropped from neutral to moderately alkaline (7.41-7.97) in the previous study to neutral to slightly alkaline (7.04-7.66) in the current study (Fig. 6).This decline resulted from complex interactions of land management practices including intensive cultivation, crop rotation and repeated application of either mineral fertilizers or organic manure (Gui et al., 2013, Li et al., 2015 and Ying et al., 2017). Results shown in Fig. 7 indicate an increase in $\mathrm{OM}$ from $8.51-11.41 \mathrm{~g} \mathrm{~kg}^{-1}$ in the previous study to $10.33-13.42 \mathrm{~g} \mathrm{~kg}^{-1}$ in the current study. Continuous application of organic manures enriched the soil with organic matter. Due to the increment in OM, CEC increased from 29.96-35.95 $\mathrm{cmockg}^{-1}$ soil in the previous study to $29.28-38.08 \mathrm{cmockg}^{-1}$ in the current study (Fig. 8).Curtin et al. (2015) and Li et al. (2017) reported a significant increase in CEC responding to long-term application of organic amendments. With the changes in soil $\mathrm{pH}$, $\mathrm{OM}$ and $\mathrm{CEC}$, the ratings were not modified and remained similar according to Riquier et al. (1970), having values of 100, 80 and 95, respectively. 


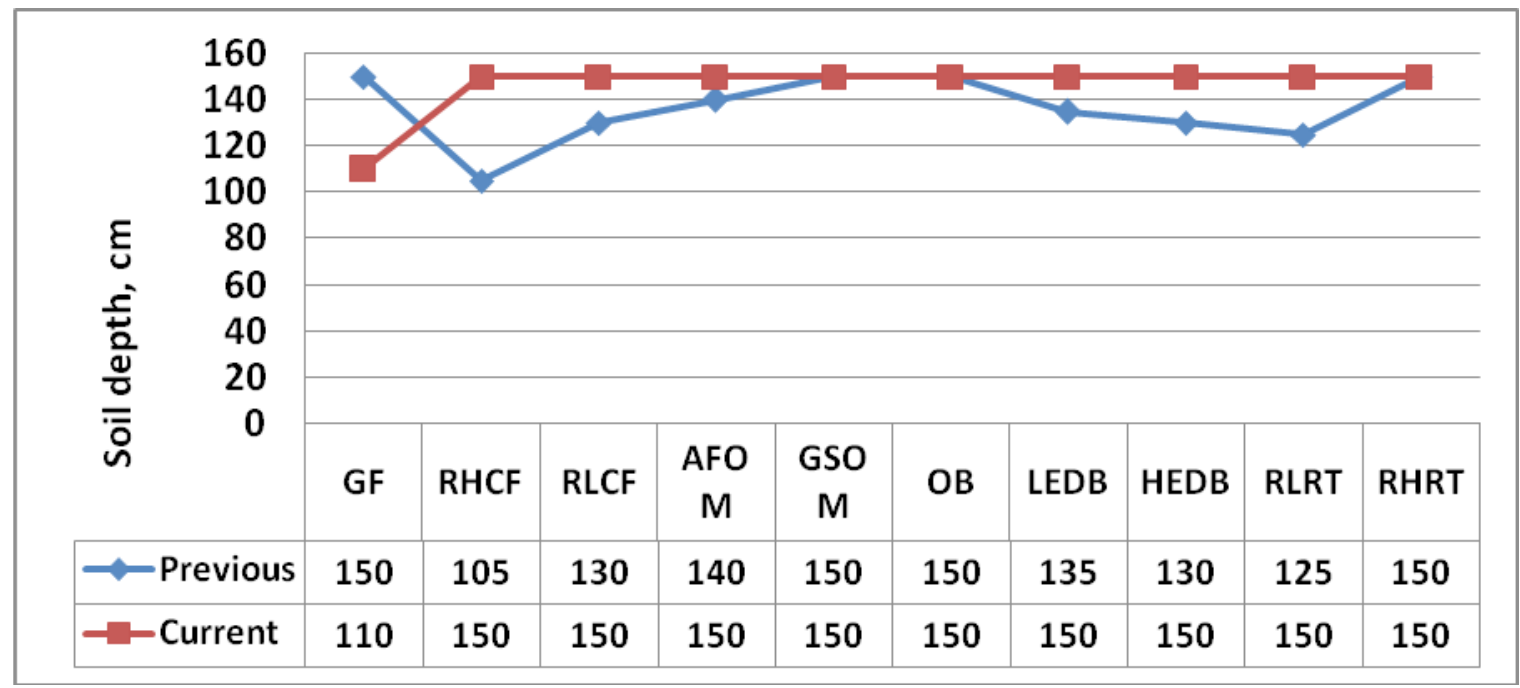

Fig. 3. Changes of soil depthover the different landforms in the studied area

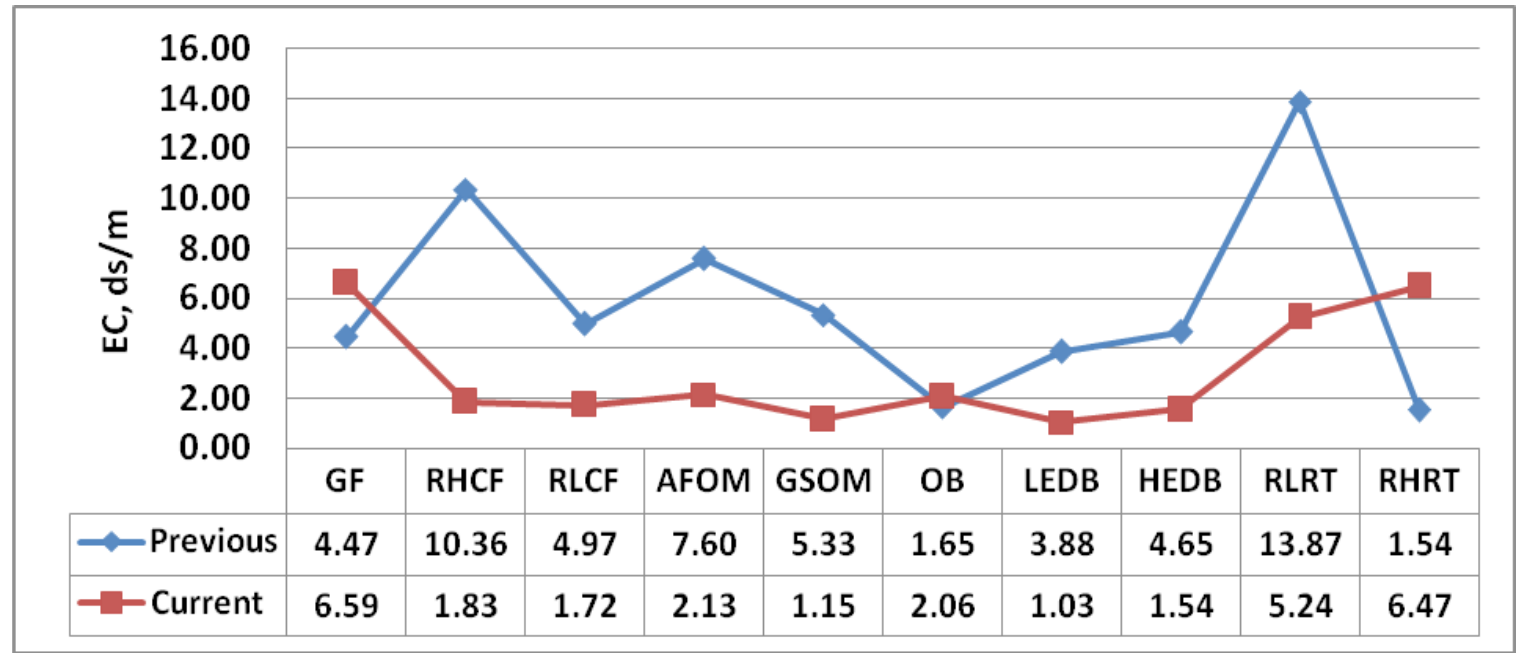

Fig. 4. Changes of EC over the different mapping unitlandforms in the studied area

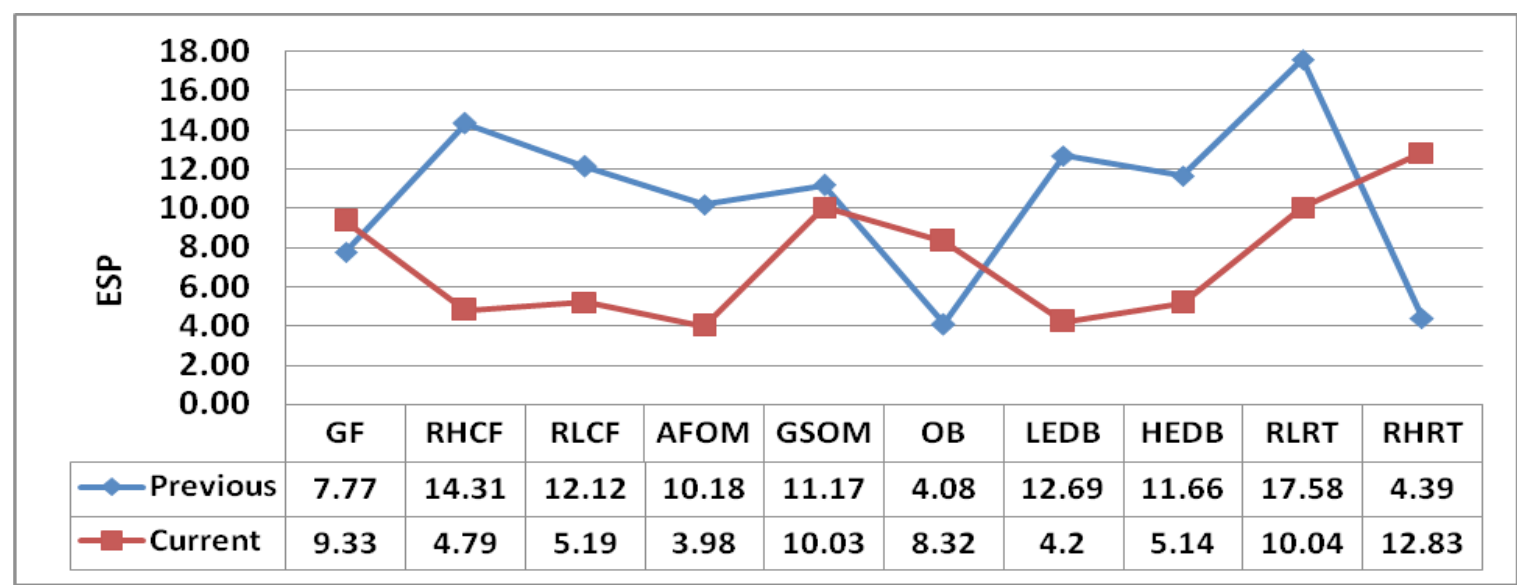

Fig. 5. Changes of ESP over the different landformsin the studied area 


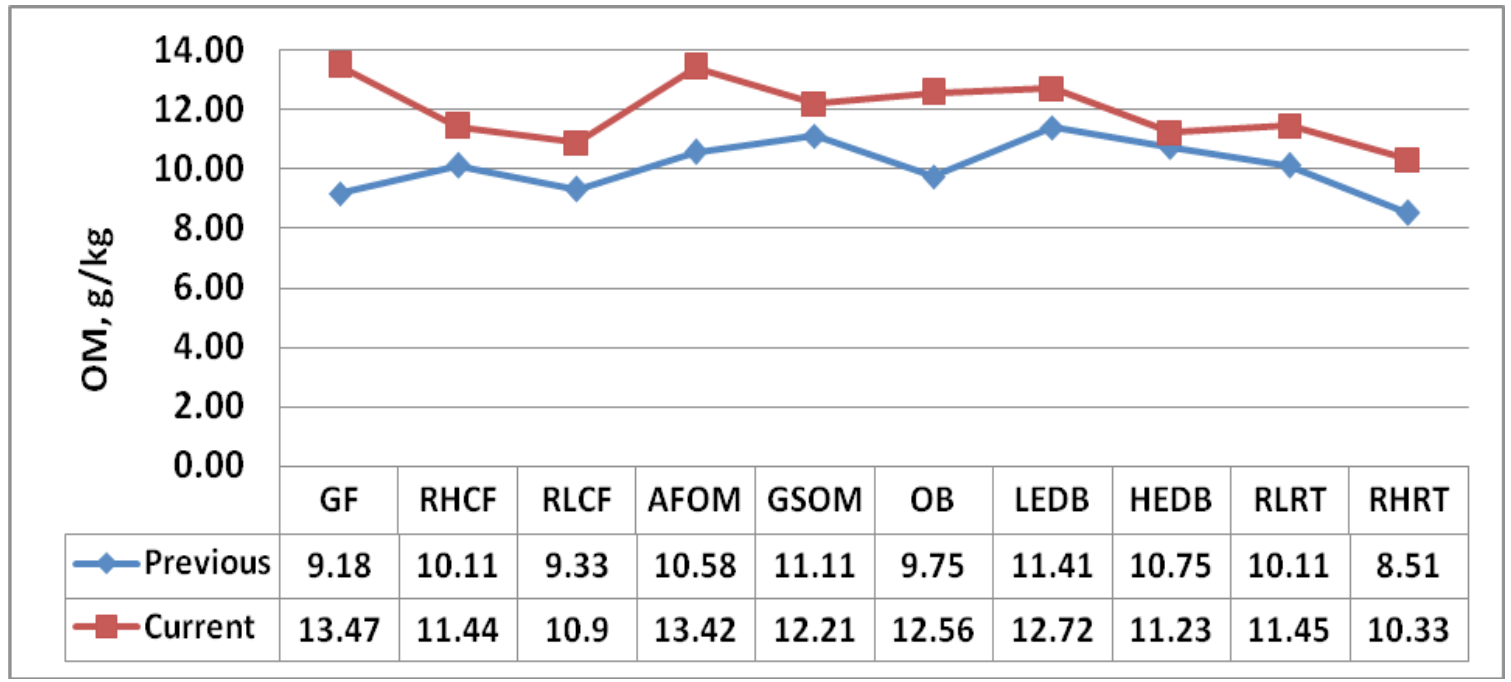

Fig. 6. Changes of soil pH over the different landforms in the studied area

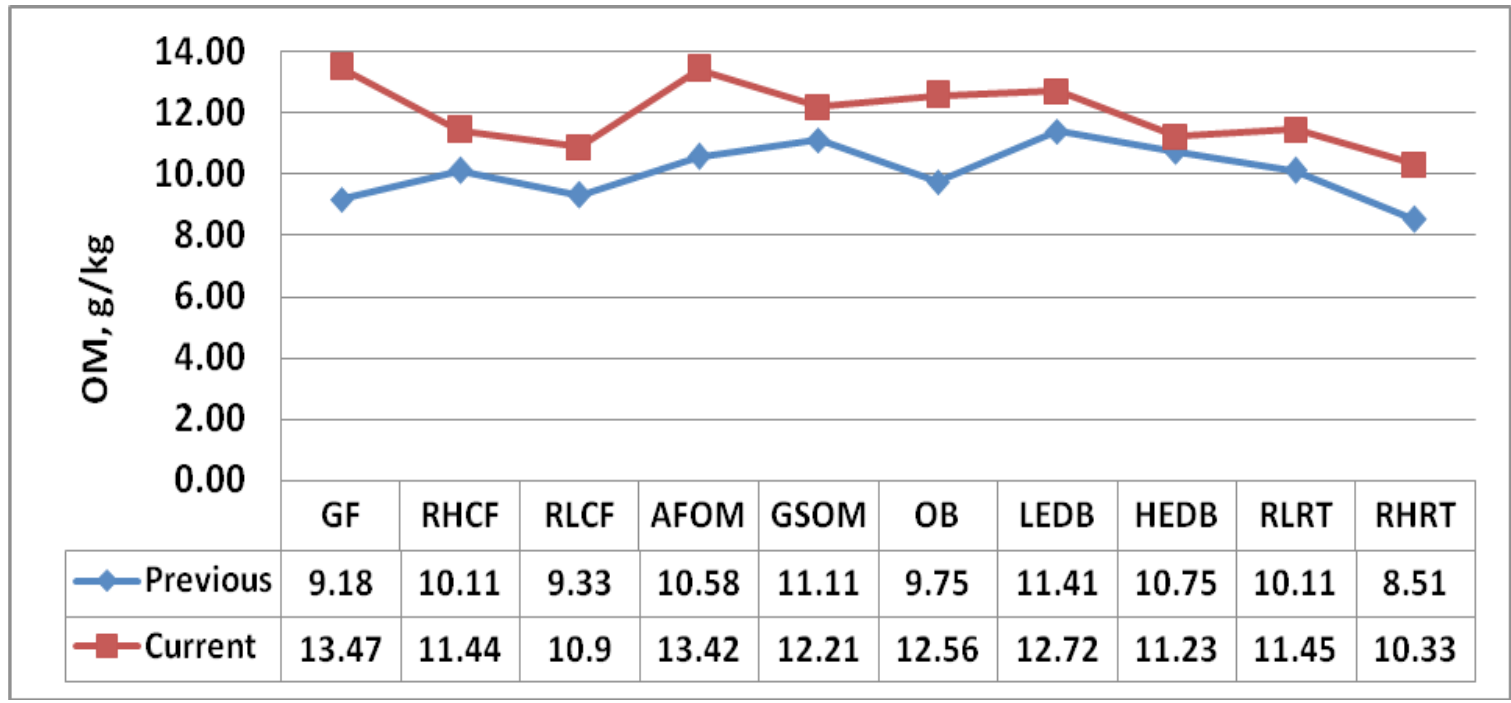

Fig. 7. Changes of OM over the different landforms in the studied area

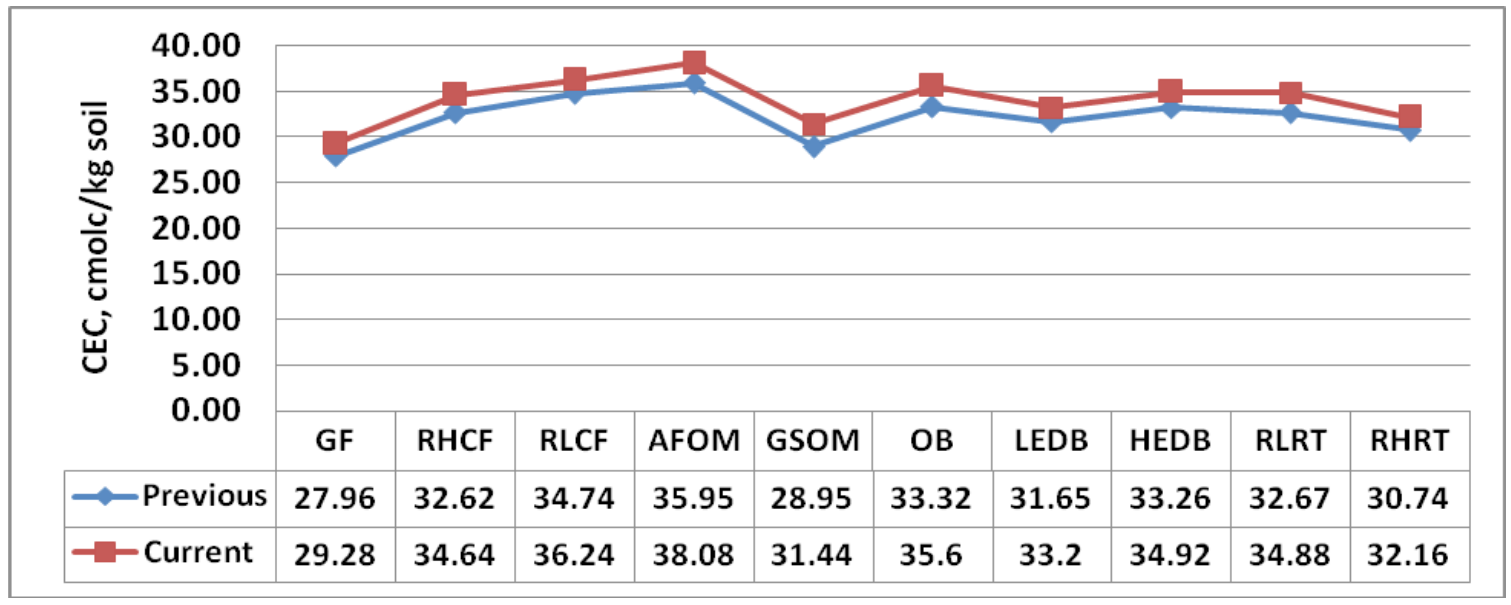

Fig. 8. Changes of CEC over the different landforms in the studied area.

Egypt. J. Soil Sci. 57, No.4 (2017) 


\section{Land productivity}

Spatial variation

Results in Table 3 and Fig. 9 and 10 indicate that the LPI in the current study ranges from 24.32 to 68.40 . The highest value occurs at the GSOM unit, where the soils have excellent productivity (grade I), while the lowest value occurs at the GF unit, where the soils have average productivity (grade III). Imperfect drainage, texture/structure and excessive salt are the main limiting factors. Precise land management practices are necessary to overcome limitations in order to improve soil productivity. These practices include constructing and improving drainage networks to lower groundwater table, leaching processes to reduce soil salinity, and addition of organic amendments to improve soil structure. On the other hand, the LPI in the previous study varied from 14.59 to 61.56. The highest value occurs at the GSOM unit, where the soils have good productivity (grade II), while the lowest value occurs at the RHCF unit, where the soils have poor productivity (grade IV). The relative extent of land productivity (Table 4) reveals that $4.60 \%$ of the soils in the current study belong to grade I (excellent), 79.30.\% belong to grade II (good) and $16.10 \%$ belong to grade III (average). The values in the previous study were $40.56 \%$ for grade II (good), $55.05 \%$ for grade III (average), and $4.39 \%$ for grade IV (poor).

\section{Temporal variation}

A comparison based on the LPI values was performed to monitor changes in soil productivity during the last five decades (Fig. 11). The changes could be discussed for each of the studied landforms as follows:

\section{Soils of the gypsiferrous flats}

These soils subjected to slight negative change, as the LPI decreased from 30.40 in the previous study to 24.32 in the current study; however, the soils remained within grade III. Increasing soluble salts is the main causative for such a change. The increment of soluble salts is related to the increased ground water table due to improper drainage.

This landform includes relatively high clay flats (RHCF) and relatively low clay flats (RLCF). A substantial positive change occurred in the RHCF unit, since the LPI increased from 14.59 to 60.80 , upgrading the soil productivity from poor to good.Positive change was also in the RLCF unit, as the LPI increased from 24.32 to 60.80 . This increase raised soil productivity from average (grade III) to good (grade II). Proper drainage leaching excessive salts and improving soil structure contributed such favorable changeswithin this landform.

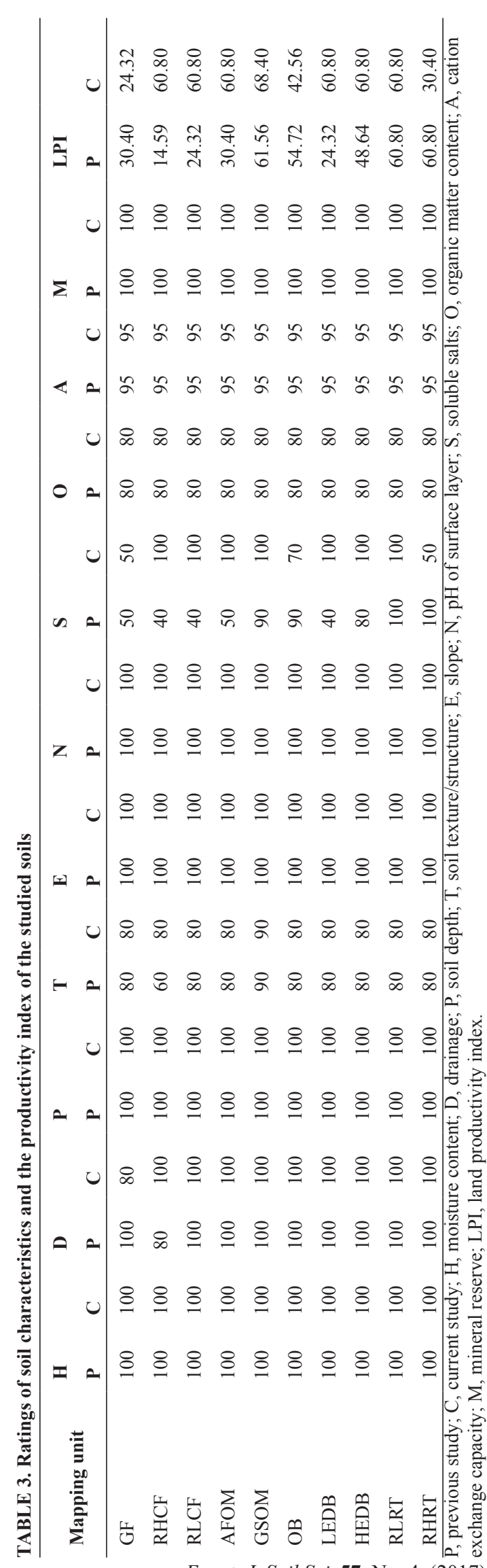

Egypt. J. Soil Sci. 57, No. 4 (2017) 
TABLE 4. The relative extent of land productivity in the studied area

\begin{tabular}{lcccccc}
\hline \multirow{2}{*}{ LPI value } & \multirow{2}{*}{ Grade } & Symbol & \multicolumn{2}{c}{ Previous study } & \multicolumn{2}{c}{ Current study } \\
\cline { 4 - 6 } & & & Area, $\mathbf{k m}^{\mathbf{2}}$ & Area, $\%$ & Area, $\mathbf{k m}^{\mathbf{2}}$ & Area, \% \\
\hline $65-100$ & Excellent & I & --- & -- & 99.99 & 4.60 \\
$35-64$ & Good & II & 881.15 & 40.56 & 1722.59 & 79.30 \\
$20-34$ & Average & III & 1195.75 & 55.05 & 349.70 & 16.10 \\
$19--8$ & Poor & IV & 95.39 & 4.39 & --- & --- \\
$0-7$ & Extremely poor to nil & V & --- & --- & --- & --- \\
\hline
\end{tabular}

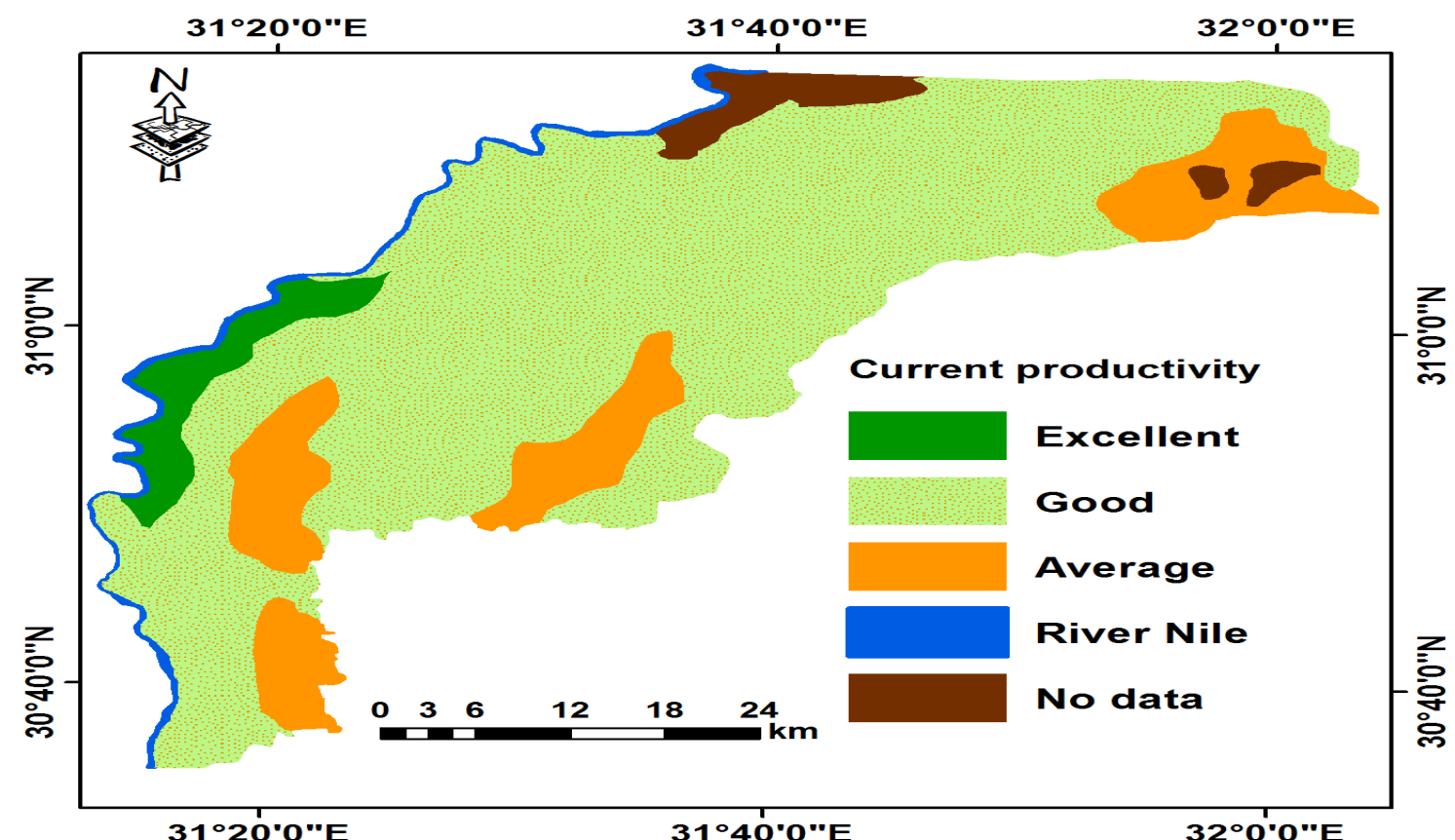

Fig. 9. Current land productivity of the studied area

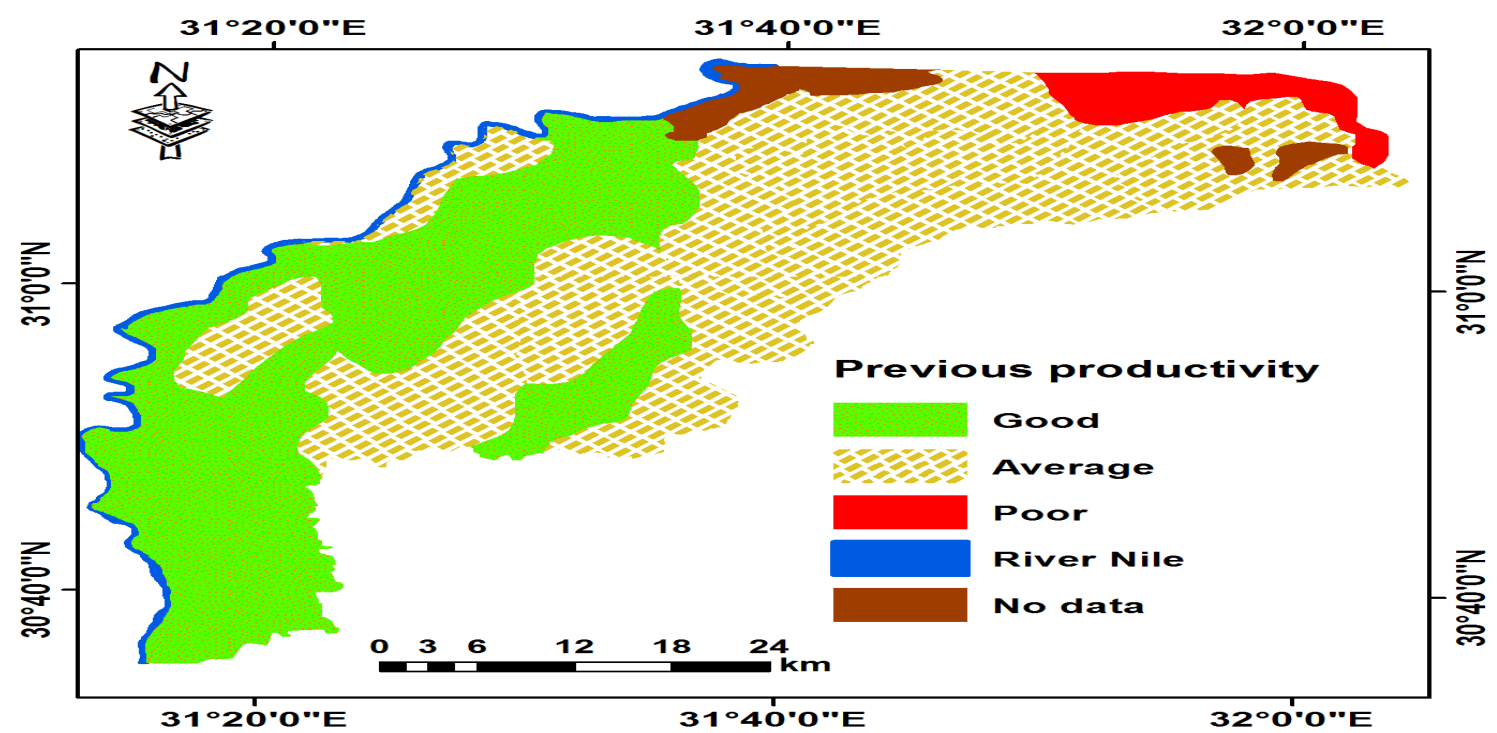

Fig. 10. Previous land productivity of the study area

Egypt. J. Soil Sci. 57, No.4 (2017) 


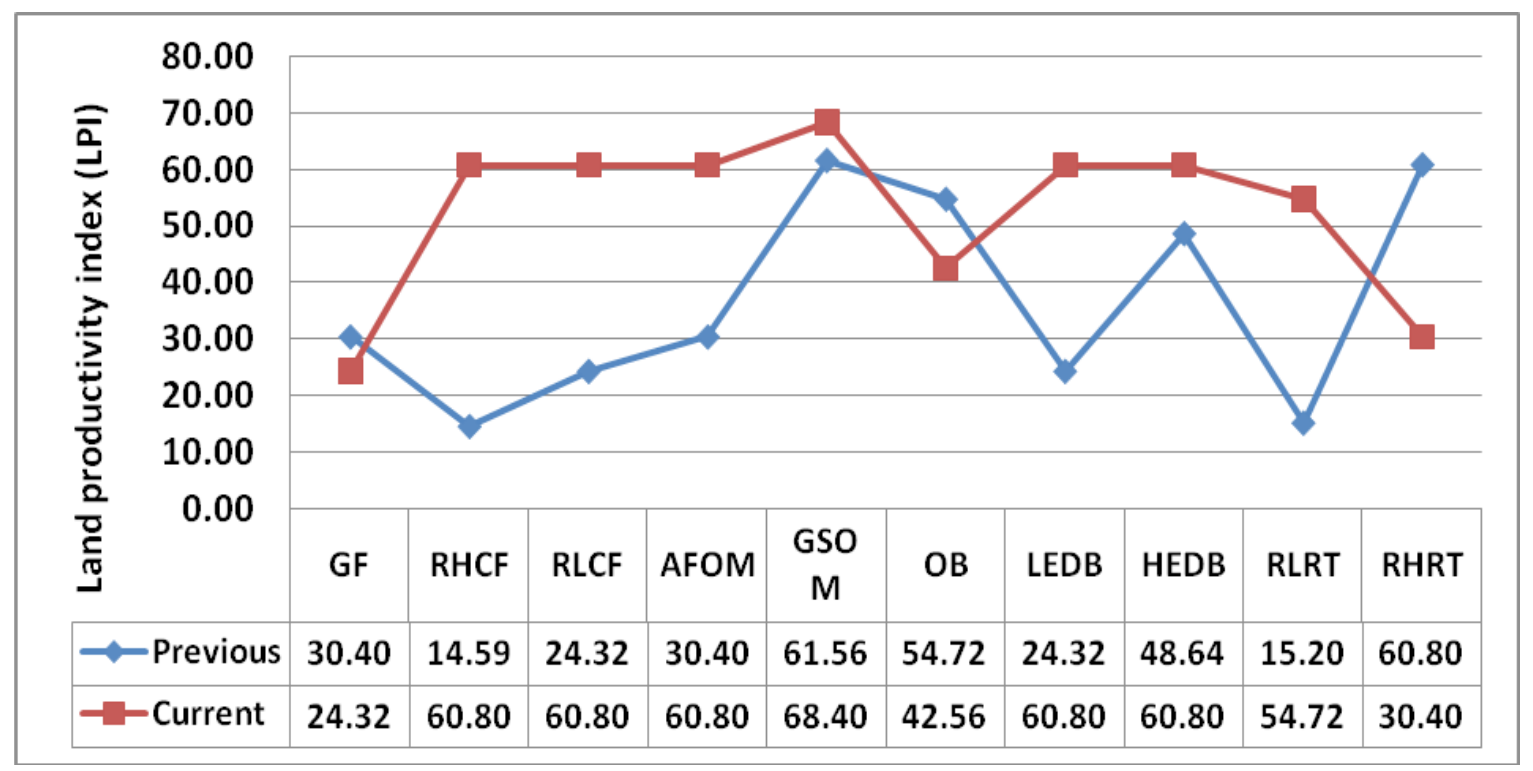

Fig. 11. Changes in the LPI over the different mapping units in the studied area

Soils of the overflow mantle

The soils are divided into almost flat overflow mantle (AFOM) and gently slope overflow mantle (GSOM). The LPI increased during the studied period from 30.40 (average) to 60.80 (good) at the AFOM unit. The slight LPI increase from 61.56 to 68.40 also placed the soils of GSOM in the highest grade; excellent. Leaching excessive salts is the key factor for upgrading soils productivity.

Soils of the overflow basin

Although the LPI decreased from 54.72 to 42.56, the soils remained having a good productivity. The increase in the salt content is the main reason for such decrease. High soluble salt content in the irrigation water or too little attention directed towards the drainage of irrigated fields may lead to increased salinity.

\section{Soils of the decantation basin}

The soils are grouped into low elevated decantation basin (LEDB) and high elevated decantation basin (HEDB). The LPI increased from 24.32 to 60.80 at the LEDB, upgrading the soils from average to good. Such increase is related to minimizing salt content in the soils. On the other hand, soils of the HEDB remained within grade II (good); however the LPI increased from 48.64 to 60.80 due to decreasing soil salinity.

Soil of the river terraces

This landform includes relatively low river terraces (RLRT) and relatively high river terraces (RHRT).Contrast notable changes were observed within this landform. The positive changes related to the RLRT, as the LPI increased from 15.20 to 54.72 , upgrading the soils from poor to good. Increasing groundwater table by means of proper drainage and leaching excessive salts led to such substantial improvement. On the other hand, the worst negative change in the current study associated with the RHRT, where the LPI decreased from 60.80 (good) to 30.40 (average). High soluble salt in the irrigation water increased soils salinity from none to slight and led to decreasing soil productivity.

\section{Conclusion}

The studied area belongs to three productivity classes; excellent, good and average.The main limiting factors are excessive salts, inadequate drainage and soil texture/structure.Changes in land productivity were observed during the last five decades. Positive changes were dominant in the majority of the studied soils $(75.98 \%)$, and the best were in the relatively high clay flat and relatively low river terraces units, where the soil productivity upgraded from poor to good. Negative changes were observed in few localities $(24.02 \%)$, and the worst was at the relatively high river terraces unit, where soil productivity downgraded from good to average. Improving soil productivity requires good land management including constructing and improving drainage networks to lower groundwater table followed by leaching processing to reduce excessive salinity, and addition of organic matter to improve soil structure. 


\section{Acknowledgment}

The author expresses his deep thanks to Prof. Dr. Ali Ahmed Abd El-Salam and Prof. Dr. Hassan Hamza Abbas, Soil and Water Department, Faculty of Agriculture, Moshtohor, Benha University for their help and encouragement during the study.

\section{References}

Abdel Kawy, W. and Ali, R. (2012) Assessment of soil degradation and resilience at northeast Nile Delta, Egypt: The impact on soil productivity. Egypt. J. Rem. Sens. Space Sci.15, 19-30.

Abdel Kawy, W.M. and Belal, A.A. (2013) Use of satellite data and GIS for soil mapping and monitoring soil productivity of the cultivated land in El-Fayoum depression, Egypt. Arab J. Geosci. 6, 723-732.

Abdou, A.A. and Shehata, M.G. (2009) Petrographical, Mineralogical and Geochemical Studies on Coresamples From Sidi Salim-1 Well, Nile Delta, Egypt. Pet. Sci. Technol. 27, 2145-2157.

Agber, P.I. and Ali, A. (2012) Evaluation of the productivity of soils in Makurdi, southern Guinea Savanna, Nigeria, using riquier index. J. Environ. Sci. Water Resour.1, 100-104.

Ali, M. (2011) Management of salt-affected soils. Practices of Irrigation \& On-farm Water Management: Volume 2. Springer, pp. 271-325.

Arnous, M.O., El-Rayes, A.E. and Green, D.R. (2015) Hydrosalinity and environmental land degradation assessment of the East Nile Delta region, Egypt. J. Coast. Conserv.19, 491-513.

Bacic, I.L.Z. (2008) Demand-driven land evaluation. Digital Soil Mapping with Limited Data. Springer, Nederland, pp. 151-162.

Badami, M.G. and Ramankutty, N. (2015) Urban agriculture and food security: A critique based on an assessment of urban land constraints. Global Food Security, 4, 8-15.

Baskan, O., Dengiz, O. and Demirag, I.T. (2017) The land productivity dynamics trend as a tool for land degradation assessment in a dryland ecosystem. Environ. Monit. Assess.189, 212.

Bents, D. and Silova, E. (2017) Model of Region's Food Security in Russia. In: Bilgin, M.H., Danis, H., Demir, E., Can, U. (Ed.), Financial Environment and Business Development: Proceedings of the 16th Eurasia Business and Economics Society Conference. Springer International Publishing,

Egypt. J. Soil Sci. 57, No.4 (2017)
Cham, pp. 217-229.

Bodaghabadi, M.B., Martinez-Casasnovas, J.A., Khakili, P., Masihabadi, M.H. and Gandomkar, A.(2015) Assessment of the FAO traditional land evaluation methods, A case study: Iranian Land Classification method. Soil Use Manag. 31, 384396.

Brocard, G.Y., Willenbring, J.K., Scatena, F.N. and Johnson, A.H. (2015) Effects of a tectonicallytriggered wave of incision on riverine exports and soil mineralogy in the Luquillo Mountains of Puerto Rico. Applied Geochem. 63, 586-598.

Ciaian, P., Paloma, S., Mary, S. and Langrell, S. (2017) Introduction. In: Paloma, S., Mary, S., Langrell, S., Ciaian, P. (Ed.), The Eurasian Wheat Belt and Food Security. Springer International Publishing, Switzerland, pp. 3-13.

Curtin, D., Fraser, P.M. and Beare, M.H. (2015) Loss of soil organic matter following cultivation of long-term pasture: effects on major exchangeable cations and cation exchange capacity. Soil Res. 53, 377-385.

Deng, X.Z., Jiang, Q.O. and Wen, X. (2011) ComputerBased Estimation System for Land Productivity. In: Lin, S., Huang, X. (Ed.), Advanced Research on Computer Education, Simulation and Modeling, $\mathrm{Pt}$ I, pp. 317-321.

Dengiz, O. (2007) Assessment of soil productivity and erosion status for the Ankara-Sogulca catchment using GIS. Int. J. Soil Sci. 2, 15-28.

Dengiz, O. and Sağlam, M. (2012) Determination of land productivity index based on parametric approach using GIS technique. Eurasian J. Soil Sci.1, 51-57.

Ding, Y., Huang, H., Wang, L., Zhang, Z.Q. and Zhang, W.H. (2014) Effect of Different Organic Matter Content on Soil Moisture Dynamics. In: Choi, S.B., Kim, Y.H., Yarlagadda, P. (Ed.), Applied Mechanics and Materials, Ii, Pts 1 and 2, pp. 481-484.

El-Baroudy, A.A. (2015) Assessing long-term changes of productivity in some Floodplain soils, Egypt, using spatial analyses techniques. Egypt. J. Soil Sci. 55, 155-170.

El-Saidi, M.T. (2002) Use of saline drainage water for irrigation, reclamation and cultivation of new land areas in Sinai Peninsula. In: Prospects for Saline Agriculture. Springer, Netherlands, pp. 57-67.

El Baroudy, A.A. (2011)Monitoring land degradation 
using remote sensing and GIS techniques in an area of the middle Nile Delta, Egypt. CATENA 87, 201208.

EMA (2011) The normals for Mansoura station, (1960 2010). Egyptian Meteorological Authority (EMA). Ministry of Civil Aviation, Cairo, Egypt.

ESRI (2014) Arc Map version 10.2. User Manual. ESRI, 380 New York Street, Redlands, California, USA.

FAO (2006) Guidelines for Soil Description. Fourth edition. FAO, Rome.

FAO (2007) Land Evaluation, towards a revised framework. FAO, Rome, Italy.

Field, D.J. (2017) Soil Security: Dimensions. Global Soil Security. Springer, pp. 15-23.

Gao, X.Y., Huo, Z.L., Bai, Y.N., Feng, S.Y., Huang, G.H., Shi, H.B. and Qu, Z.Y. (2015) Soil salt and groundwater change in flood irrigation field and uncultivated land: a case study based on 4-year field observations. Environ. Earth Sci.73, 2127-2139.

Gouda, A.A., Hosseini, M. and Masoumi, H.E. (2016) The Status of Urban and Suburban Sprawl in Egypt and Iran. Geoscape, 10, 1-15.

Gui, R.Y., Sun, X. and Zhuang, S.Y. (2013) Soil Acidification in Phyllostachys praecoxf. preveynalis Cultivation with Intensive Management. Commun. Soil Sci. Plant Anal. 44, 3235-3245.

Kudrat, M. and Saha, S. (1993) Land productivity assessment and mapping through integration of satellite and terrain slope data. J. Indian Soc. Remote, 21, 157-166.

Lairon, D. (2010) Nutritional quality and safety of organic food. A review. Agron. Sustain. Dev. 30, 33-41.

Li, J., Cooper, J.M., Lin, Z.A., Li, Y.T., Yang, X.D. and Zhao, B.Q. (2015) Soil microbial community structure and function are significantly affected by long-term organic and mineral fertilization regimes in the North China Plain. Appl. Soil Ecol. 96, 75-87.

Li, Q., Guo, X., Chen, L., Li, Y., Yuan, D., Dai, B. and Wang, S. (2017) Investigating the spectral characteristic and humification degree of dissolved organic matter in saline-alkali soil using spectroscopic techniques. Front. Earth Sci. 1-9.

Mohamed, E.S., Belal, A. and Saleh, A. (2013) Assessment of land degradation east of the Nile Delta, Egypt using remote sensing and GIS techniques. Arab. J. Geosci. 6, 2843-2853.

Mohamed, N.N. (2016) Land Degradation in the Nile Delta. In: Negm, A.M. (Ed.), The Nile Delta, Springer Berlin Heidelberg, Berlin, Heidelberg, pp. $1-30$.

Mueller, L., Behrendt, A., Schalitz, G. and Schindler, U. (2005) Above ground biomass and water use efficiency of crops at shallow water tables in a temperate climate. Agric. Water Manag.75, 117-136.

Murphy, B. (2017) Testing the Links Between Soil Security, Sustainable Land Management Practices and Land Evaluation. Global Soil Security. Springer, pp. 87-97.

Riquier, J., Bramao, D.L. and Cornet, J.P. (1970) A new system of soil appraisal in terms of actual and potential productivity. FAO, Soil Resources, Development and Conservation Service, Land and Water Development Division. FAO, Rome.

Rong, L., Duan, X.W., Feng, D.T. and Zhang, G.L. (2017) Soil Moisture Variation in a Farmed DryHot Valley Catchment Evaluated by a Redundancy Analysis Approach. Water, 9.

Ruseckas, J., Grigaliunas, V., Suchockas, V. and Pliura, A. (2015) Influence of ground water table depth, ground vegetation coverage and soil chemical properties on forest regeneration in cutovers on drained fen habitats. Baltic Forestry, 21, 152-161.

Sasmal, J. (2016) Uses of Land, Agricultural Price and Food Security. Resources, Technology and Sustainability. Springer, pp. 181-235.

Setia, R., Verma, V. and Sharma, P. (2012) Soil Informatics for Evaluating and Mapping Soil Productivity Index in an Intensively Cultivated Area of Punjab, India J. Geogr. Inform. Sys. 4, 71.

Soil Survey Staff (2014a) Keys to soil taxonomy. $12^{\text {th }}$ ed. United States Department of Agriculture, Natural Resources Conservation Service, Washington, DC.

Soil Survey Staff (2014b) Soil survey field and laboratory methods manual. Soil Survey Investigations Report No. 51, Version 2.0. U.S. Department of Agriculture, Natural Resources Conservation Service.

SWERI (1965) Soil survey of Dekernis District, ElDakahlyia Governorate. May, 1965.

SWERI (1968) Soil survey of Meet-Ghamr District, ElDakahlyia Governorate. August, 1968.

SWERI (1969) Soil survey of El-Senbilawein Egypt. J. Soil Sci. 57, No. 4 (2017) 
District, El-Dakahlyia Governorate. May, 1969.

Van-den Akker, J., Simmons, C. and Hutson, J., (2011) Salinity effects from evaporation and transpiration under flood irrigation. J. Irrig. Drain. Eng. 137, 754-764.

Van Breemen, N., Finlay, R., Lundstrom, U., Jongmans, A.G., Giesler, R. and Olsson, M., (2000) Mycorrhizal weathering: A true case of mineral plant nutrition? Biogeochem. 49, 53-67.

Wahab, H.S.A. and Stanley, D.J. (1991) Clay mineralogy and the recent evolution of the north-central Nile Delta, Egypt. J. Coast. Res. 7, 317-329.

Wahba, M.A.S. (2017) Assessment of options for the sustainable use of agricultural drainage water for irrigation in Egypt by simulation modelling. Irrig. Drain. 66, 118-128.

Ying, J.Y., Li, X.X., Wang, N.N., Lan, Z.C., He, J.Z. and Bai, Y.F. (2017) Contrasting effects of nitrogen forms and soil $\mathrm{pH}$ on ammonia oxidizing microorganisms and their responses to long-term nitrogen fertilization in a typical steppe ecosystem. Soil Biol. Biochem.107, 1018.

Zhang, S.P., Shao, M.G. and Li, D.F. (2017) Prediction of soil moisture scarcity using sequential Gaussian simulation in an arid region of China. Geoderma, 295, 119-128.

Zhou, Q., Wu, W. and Liu, H.B. (2012) Evaluation of Cultivated Land Productivity of Wanyuan County, Sichuan Province Using GIS. Advanced Technology in TeachingProceedings of the 2009 3rd International Conference on Teaching and Computational Science (WTCS 2009). Springer, pp. 919-926.

(Received: $12 / 2 / 2017$ )

accepted: 5 / 7 /2017)

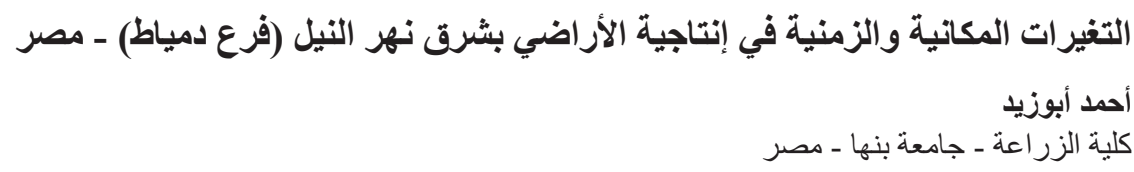

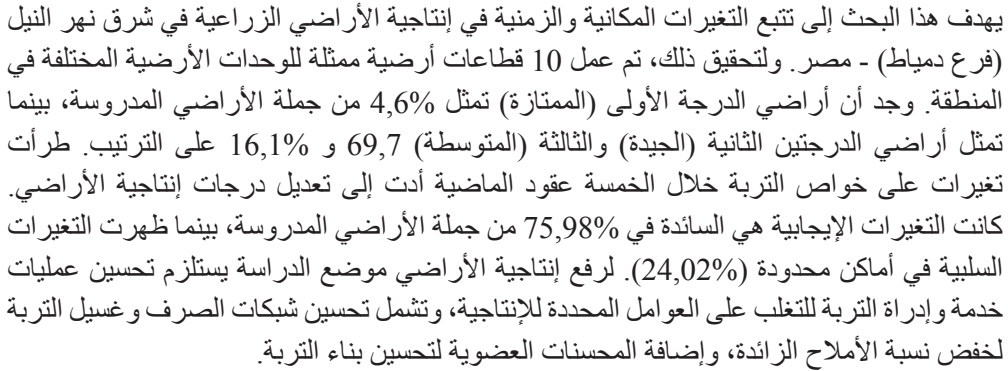

Egypt. J. Soil Sci. 57, No.4 (2017) 